\title{
Larval habitats of the Anopheles farauti and Anopheles lungae complexes in the Solomon Islands
}

Tanya L. Russell ${ }^{1 *}$ (D), Thomas R. Burkot ${ }^{1}$, Hugo Bugoro ${ }^{2}$, Allan Apairamo², Nigel W. Beebe ${ }^{3,4}$, Weng K. Chow ${ }^{5}$, Robert D. Cooper ${ }^{5}$, Frank H. Collins ${ }^{6}$ and Neil F. Lobo ${ }^{6}$

\begin{abstract}
Background: There is an urgent need for vector control tools to supplement long-lasting insecticidal nets (LLINs) and indoor residual spraying; particularly in the Solomon Islands where the primary vector, Anopheles farauti, is highly anthropophagic and feeds mainly outdoors and early in the evening. Currently, the only supplementary tool recommended by the World Health Organization is larval source management (LSM). The feasibility and potential effectiveness of LSM requires information on the distribution of anophelines, the productivity of larval habitats and the potential impacts of larval control on adult fitness.

Methods: The distribution of anophelines in Central and Western Provinces in the Solomon Islands was mapped from cross-sectional larval habitat surveys. The composition and micro-distribution of larval instars within a large permanent river-mouth lagoon was examined with a longitudinal survey. Density-dependent regulation of An. farauti larvae was investigated by longitudinally following the development and survival of different densities of first instars in floating cages in a river-mouth lagoon.

Results: Five anopheline species were molecularly identified from a range of fresh and brackish water habitats: An. farauti s.s., An. hinesorum, An. lungae, An. nataliae and An. solomonis. The most common habitats used by the primary malaria vector, An. farauti, were coastal lagoons and swamps. In the detailed study of lagoon micro-productivity, An. farauti was non-uniformly distributed with highest densities found at collections sites most proximal and distal to the mouth of the lagoon. The survival of An. farauti larvae was more than twofold lower when larvae were held at the highest experimental density (1 larva per $3.8 \mathrm{~cm}^{2}$ ) when compared with the lowest density (1 larva per $\left.38 \mathrm{~cm}^{2}\right)$.

Conclusions: The only documented major malaria vector collected in larval surveys in both Central and Western Provinces was An. farauti. Lagoons and swamps, the most common, largest and (potentially) most productive larval sites of this malaria vector, were "few, fixed and findable" and theoretically, therefore, amenable to successful LSM. However, the immense scale and complexity of these ecosystems in which An. farauti larvae are found raises questions regarding the ability to effectively control the larvae, as incomplete larviciding could trigger density dependent effects resulting in increased larval survivorship. While LSM has the potential to significantly contribute to malaria control of this early and outdoor biting vector, more information on the distribution of larvae within these extensive habitats is required to maximize the effectiveness of LSM.
\end{abstract}

Keywords: Solomon Islands, Malaria, Anopheles farauti, Species distribution, Density dependent development

\footnotetext{
*Correspondence: tanya.russell@jcu.edu.au

${ }^{1}$ Australian Institute of Tropical Health and Medicine, James Cook

University, Cairns, QLD 4870, Australia

Full list of author information is available at the end of the article
} 


\section{Background}

The Solomon Islands is currently implementing countrywide intensified malaria control using universal distribution of long-lasting insecticidal nets (LLINs) and indoor residual spraying (IRS). Unfortunately, the main malaria vector in the Solomon Islands, Anopheles farauti, displays behavioural resistance to indoor vector control by blood feeding predominantly when people are outdoors [1]. This behavioural shift first occurred in response to IRS with DDT in the 1970s [2, 3] and has persisted in the Solomon Islands with LLINs being the primary malaria vector control strategy [4-7]. Despite the early and outdoor biting behaviour of An. farauti, LLINs and IRS have had a significant impact on malaria transmission. However, achieving malaria elimination will require additional vector control to minimize outdoor transmission. The only outdoor strategy recommended by the World Health Organization is larval source management (LSM) [8] and this has the potential to limit transmission both indoors and outdoors. Larval source management is only recommended in areas where the larval habitats are few in number, fixed in location and easily accessible [9]. To ascertain the feasibility of implementing LSM in the Solomon Islands, information on the types of larval habitats utilized by vectors including their location in proximity to villages is needed.

Nine species of anophelines occur in the Solomon Islands: six members of the An. punctulatus group: An. farauti, An. irrenicus, An. hinesorum, An. punctulatus, An. koliensis and An. rennellensis [10, 11]; as well as three members of the An. lungae complex: An. lungae, An. solomonis and An. nataliae [12]. Of these, the only known malaria vectors in the Solomon Islands are $A n$. farauti, An. punctulatus and An. koliensis. Anopheles punctulatus and An. koliensis became uncommon after IRS with DDT was extensively used for malaria vector control tool in the 1970s [13]. Larvae of An. farauti, are found within a kilometre of the coast in both fresh and brackish water ( $\geq 70 \%$ seawater) $[14,15]$. Freshwater larval habitats of An. farauti include both natural and man-made depressions such as drains, vehicle tracks, foot prints, pig wallows and ground-pools $[5,16]$ that are dependent on rainfall $[17,18]$. Large numbers of An. farauti are believed to be associated with large, permanent, brackish water lagoons or swamps that form behind sandbars that block the flow of water into the sea [17-19] as high adult biting densities and malaria parasite rates are associated with villages proximal to these coastal habitats [20,21].

The population dynamics of mosquitoes are influenced by both intrinsic and exogenous processes [22-25]. If density effects operate on mosquito larvae in large larval habitats, the impact of interventions targeting anopheline larval abundance will be disproportionate to the density of the anopheline populations' (linear reductions in populations may not result in linear reductions in productivity or fitness). The majority of studies on density-dependent regulation of mosquito larvae in small aquatic habitats were conducted under controlled laboratory or in "semi-field" conditions. Generally, these studies have shown that phenotypic traits which mediate individual fitness (e.g. body size) in larvae and adults are optimized at low larval population densities [26-28]. Studies to define density-dependence of mosquitoes in large larval habitats are needed. In the Solomon Islands, An. farauti use large lagoons as well as smaller and more temporary aquatic sites as larval habitats [19]. Prior to attempting larval control in the Solomon Islands, data on the distribution and abundance of categories of larval habitats are required and the potential role of larval density dependence on adult fitness needs to be defined.

\section{Methods}

\section{Study sites}

The study was conducted in Central and Western Provinces in the Solomon Islands where small villages are mainly found in coastal areas. The climate of the region is hot and wet; the median annual rainfall in Central Province is $2837 \mathrm{~mm}$ (based on 43 years of data collected from Tulagi; [29]). Annual rainfall estimates for Western Province are $2667 \mathrm{~mm}$ from Gizo (based on 28 years of data up to 1952; [29]) and $3725 \mathrm{~mm}$ from Munda (based on 11 years of data from 1999-2009; Solomon Islands Bureau of Meteorology, Unpublished data). Although rain falls throughout the year, relatively less rain falls between May to September. The mean annual temperature on the coast is $26^{\circ} \mathrm{C}$ and is reasonably constant throughout the year. Mean daily temperatures range between 24 and $30{ }^{\circ} \mathrm{C}$. Malaria is primarily transmitted by An. farauti s.s.

\section{Larval distribution}

The distribution of anophelines was investigated by larval presence-absence surveys. The surveys were focused within $2 \mathrm{~km}$ of the coast line, as this is where villages are located. Larval habitats were categorized as one of six classes and locations recorded by GPS. Surveys were conducted from August to September 2011 in Central Province $\left(9^{\circ} 0^{\prime} \mathrm{S}, 159^{\circ} 45^{\prime} \mathrm{E}\right)$ and in February and May 2013 in Western Province $\left(8^{\circ} 0^{\prime} \mathrm{S}, 157^{\circ} 0^{\prime} \mathrm{E}\right)$. In Central Province, 14 villages were surveyed on the islands of Ngella Sule and Tulagi Islands. In Western Province, 54 villages were surveyed on the islands of Vella Lavella, Ranonnga, Gizo, Kolombangara, Vonavona, Kohinggo and New Georgia Islands. Potential larval habitats were sampled with $250 \mathrm{ml}$ dippers and larval samples were stored in $70 \%$ ethanol in micro-centrifuge tubes for subsequent identification by molecular analysis of the internal transcribed spacer region II (ITS2) of the ribosomal DNA [30]. 


\section{Lagoon micro-habitats}

The micro-distribution of larval instars at different sites within a large permanent river-mouth lagoon in Haleta village, Central Province, Solomon Islands was evaluated [7]. The lagoon was a known larval habitat that forms when surface water run-off accumulates behind a sand bar that prevents drainage to the sea. After periods of heavy rain, the sandbar breaks and releases the accumulated water to the ocean and the area of the larval habitat is reduced. Hereafter, this larval habitat will be referred to as the lagoon. The numbers of the different anopheline larval instars were monitored daily at five stations $(1 \times 5 \mathrm{~m}$; Fig. 1) along the northern edge of the lagoon over 10 consecutive days from the 2nd-11th December 2012. Each station was sampled once daily by 10 dips with a standard $250 \mathrm{ml}$ dipper. The number of larvae by instar was recorded per dip. The water temperature and salinity was concurrently measured at each station with a thermometer and a hand held refractometer (Atago Co. Ltd, Japan), respectively.

\section{Density dependent development}

Density-dependent regulation of mosquito larvae was investigated by seeding first instar An. farauti larval at different densities into floating larval cages encompassing a surface are of $380 \mathrm{~cm}^{2}$ (diameter $22 \mathrm{~cm}$; Fig. 2). The larval cages permitted exchange of water and microfora with the habitat in which they were placed but excluded the entry of predators or other fauna. The larval cages tracked the temperature, nutrition and other environmental conditions in the permanent larval habitat in which they were placed.

Wild-caught female An. farauti captured by human landing catches (HLC) (see $[1,7,31]$ ) were used to generate the F1 first instars used here. Ethical approvals for conducting HLC were obtained from the National Health Research and Ethics Committee, Solomon Islands (0205-2011), the James Cook University Human Research Ethics Committee, Australia (H4122) and the University Hospitals Case Medical Centre Institutional Review Board for Human Investigation, USA (05-11-11). Bloodfed specimens from HLCs were isolated and placed into $70 \mathrm{ml}$ plastic specimen jars holding a piece of damp cotton-wool covered with filter paper on the bottom as an oviposition substrate. The top of each oviposition chamber was covered with mosquito netting overlaid with damp cotton-wool to ensure high humidity. Filter papers with eggs wer transferred into a petri dish containing rain water for hatching. F1 first instars from wild-caught females were mixed and allocated to larval cages at densities of 10, 25, 50 and 100 per larval cage (i.e. 1 larva per $38,15.2,7.6$ and $3.8 \mathrm{~cm}^{2}$, respectively) with five replicates of each density. For each treatment group the survival of larvae was monitored daily over 10 consecutive days

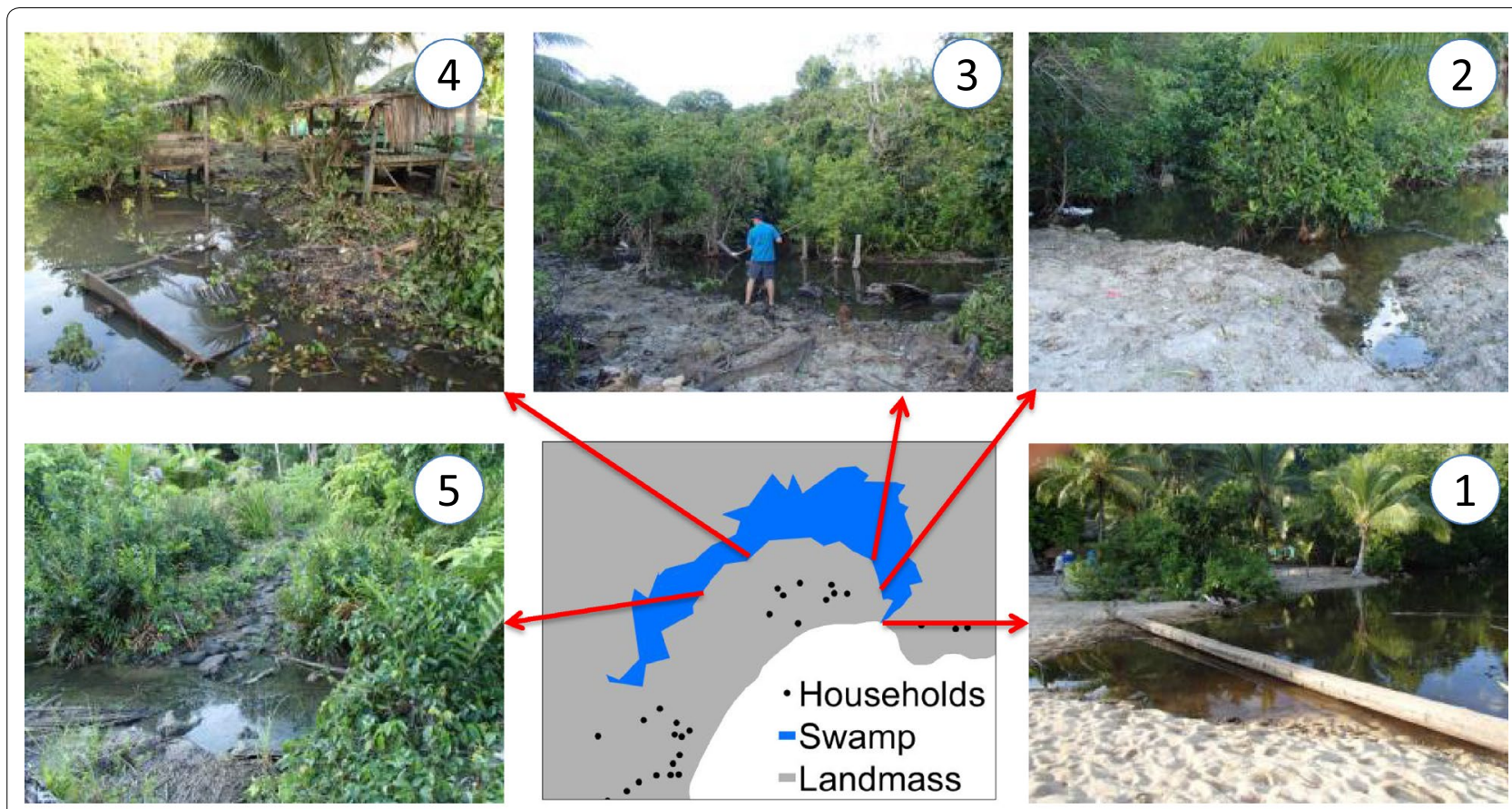

Fig. 1 Images and locations of the sampling stations used to examine micro-productivity of An. farauti larvae in Haleta Village, Central Province, Solomon Islands 


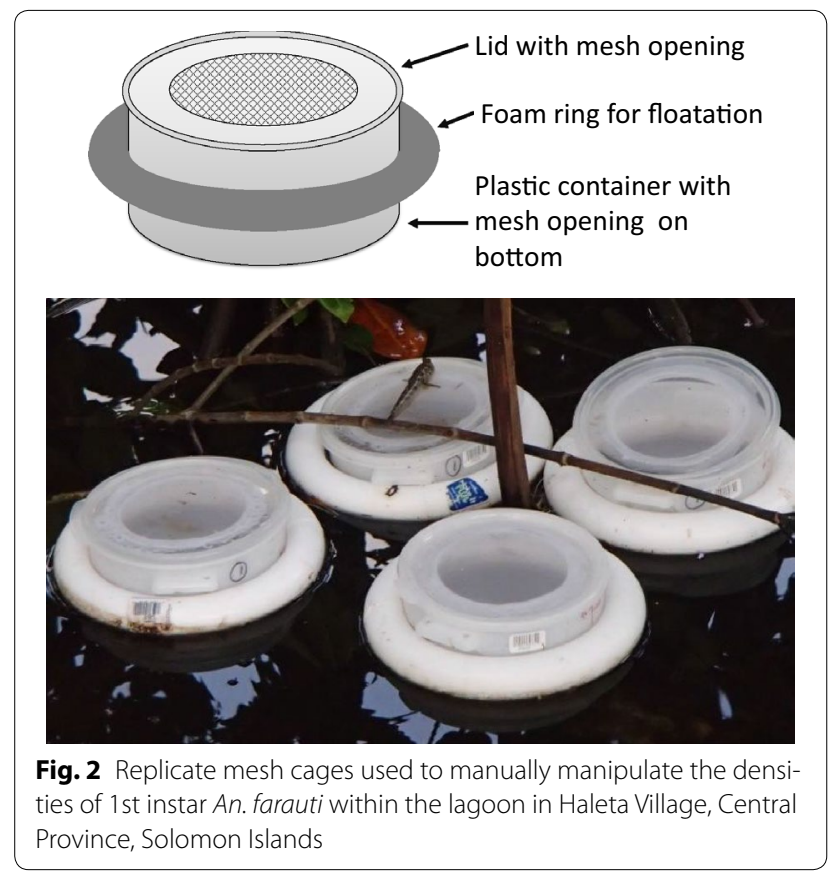

from the 2nd-11th December 2012. Larval survival was defined as total larval present at a time point divided by the total released into the cage.

\section{Statistical analysis}

For the larval distribution study, three related data sources were created: (1) the geo position of each site surveyed (shapefile); (2) the field survey conducted during each site survey (tabular); and (3) the molecular data containing the species identifications of the larval samples (tabular) [32]. The data for each source was linked with a unique identifier that was allocated to each site during the PDA-based survey.

For lagoon micro-productivity, a dataset was constructed that detailed the total number of anophelines per dip, and scored for presence as 0 (negative) or 1 (positive for larvae) for each dip [32]. The influence of location (sampling stations) on both the presence and density of larvae was analysed with generalized linear models (GLMs). The influence of the two environmental factors, water temperature and salinity, with both the presence and density of larvae was analysed with generalized linear mixed models (GLMMs) with location as a subject variable to account for repeated sampling. The distributions for the models were: (1) binary data (presence or absence) fitted to a binomial distribution with a logit link function and (2) count data (density) fitted to a negative binomial distribution with a log link function because data were not normally distributed.
The density-dependent regulation of mosquito larvae was analysed using a Cox regression to compare the survival of mosquito larvae held at different densities [32]. The Cox regression determined the relative risk of dying (hazard ratios) for each density group compared with the lowest density tested (10 larvae per cage [ 1 larva per $\left.38 \mathrm{~cm}^{2}\right]$ ). The model was weighted by the replicate number to account for longitudinal sampling. All analyses were conducted using the $R$ package V3.1.2 [33].

\section{Results}

\section{Larval distribution}

Anopheline larvae were collected from 108 larval habitats (58 sites in Central Province and 50 sites in Western Province) (Figs. 3, 4). Overall 391 specimens of five species were identified by PCR: An. farauti s.s., An. hinesorum, An. lungae, An. nataliae and An. solomonis. Anopheles farauti s.s. and An. hinesorum were the most abundant and widespread species found in both provinces. Anopheles lungae and An. nataliae were present but less common in both provinces. Anopheles solomonis was only found in Central Province. The anophelines were found across a range of larval habitats: coastal lagoons and swamps, drains, transient pools, man-hade holes, riverine and spring wells (Table 1). Both An. farauti s.s. and An. hinesorum were found in all habitat classes, with the highest prevalence habitat being coastal lagoons and swamps. The most commonly used habitat for An. lungae was riverine areas.

\section{Lagoon micro-productivity}

A total of 408 anopheline larvae were collected; $56 \%$ $(\mathrm{n}=227)$ were early instars (I-II) and $44 \%(\mathrm{n}=181)$ were late instars (III-IV). The location of the sampling station along the length of the lagoon influenced both the presence $\left(x^{2}=13.26, \mathrm{df}=4, \mathrm{p}=0.001\right)$ and density $\left(x^{2}=22.92, \mathrm{df}=4, \mathrm{p}<0.001\right)$ of larvae per dip. The larval density was highest at the monitoring stations most proximal and distal from the sandbar behind which the lagoon formed (stations 1 and 5; Table 2). The water temperature was fairly uniform across the sampling stations, ranging from 30.8 to $31.6{ }^{\circ} \mathrm{C}$, with salinity diminishing from 1 ppt at the station closet to the sandbar to 0 ppt at the site most distal from the sandbar (Table 2). Evidence for an impact of either presence or density of larvae by either water temperature $(\beta=0.37, \mathrm{df}=43, \mathrm{p}=0.359$; $\beta=0.001, \mathrm{df}=43, \mathrm{p}=0.995$, respectively) or salinity $(\beta=-0.11, \mathrm{df}=43, \mathrm{p}=0.904 ; \beta=0.109, \mathrm{df}=43$, $\mathrm{p}=0.301$, respectively) was not found.

\section{Density dependent development in the lagoon}

The survival of An. farauti larvae was more than twofold lower when larvae were held at the highest experimental 


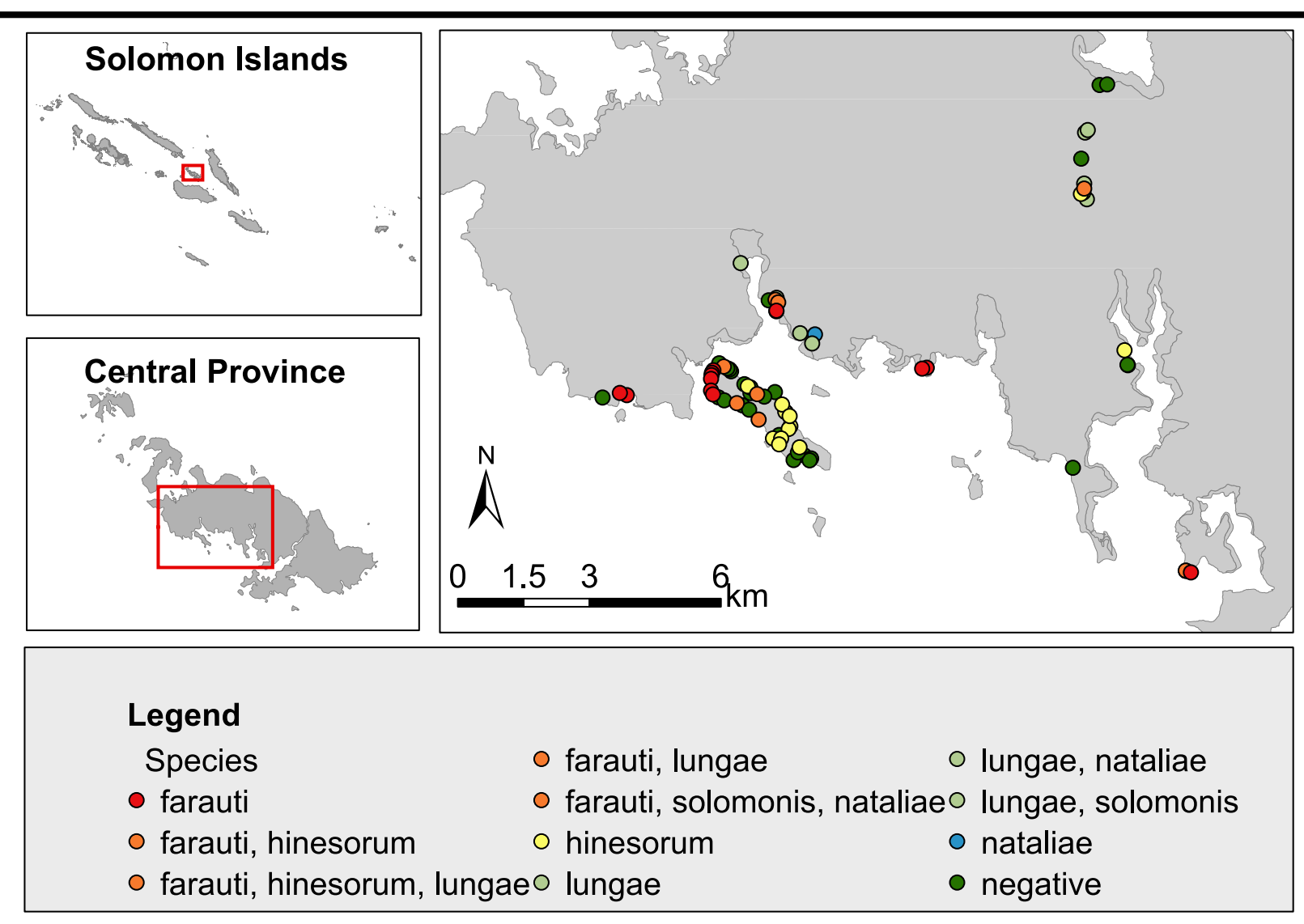

Fig. 3 Species distribution of Anopheline fauna based on larval surveys conducted in Central Province, Solomon Islands. The Islands included in the survey were Ngella Sule and Tulagi Islands

density (100 per cage or 1 larva per $3.8 \mathrm{~cm}^{2}$ ) when compared with the lowest density (10 per cage or 1 larva per $38 \mathrm{~cm}^{2}$; Hazard ratio $[\mathrm{HR}]=2.11$, se $=0.21, p=0.0003$; Fig. 5). The survival of larvae at densities of 25 (1 larva per $\left.15.2 \mathrm{~cm}^{2}\right)$ and $50\left(1\right.$ larva per $\left.7.6 \mathrm{~cm}^{2}\right)$ per cage was not significantly different from 10 per cage (25 larvae: $\mathrm{HR}=1.24$, se $=0.23, p=0.351 ; 50$ larvae: $\mathrm{HR}=1.45$, se $=0.21, p=0.082$ ).

For the lowest experimental density (10 per cage) the surviving larvae $(\mathrm{n}=31)$ all pupated with a cumulative 14 adults emerging by day 9 following larval release into the cages. The development rate was delayed at higher densities. Adults emergence was not seen from any of the other densities with the exception of two undersized (by visual inspection) adults from the highest density cage (holding 100 larvae). Only 8 of the surviving 68 (11.7\%) larvae pupated by day 10 in the 25 larvae per cage experimental density while only 10 of the surviving 131 larvae (7.6 \%) pupated in the 100/cage experimental density. Larval and pupal sizes diminished with increasing density based on a visual inspection.

\section{Discussion}

During mosquito surveys conducted in the early 1970s, An. farauti, An. punctulatus and An. koliensis were found on all the main islands in the Solomon Islands except Temotu Province [13, 34]. In the Solomon Islands, extensive DDT-IRS was conducted during the 1960s and 1970s and had a significant impact on population densities: after repeated spray rounds these highly endophagic species became difficult to find [2, 34, 35]. Both An. punctulatus and An. koliensis were found on Malaita in 1987 [36], with this being the last record of An. koliensis in the Solomon Islands. Anopheles punctulatus was found during the 1990s on both Guadalcanal and Malaita [10, 37]. Mosquito surveys have not been conducted since the early 1970s in Central Province [3]. In Western Province, a limited survey was conducted (in Titiana village) during the early 1990s and only $A n$. farauti was found [37]. The malaria vectors, $A n$. punctulatus and An. koliensis, were not identified in this study during the extensive larval habitat surveys in Central and Western Provinces. 

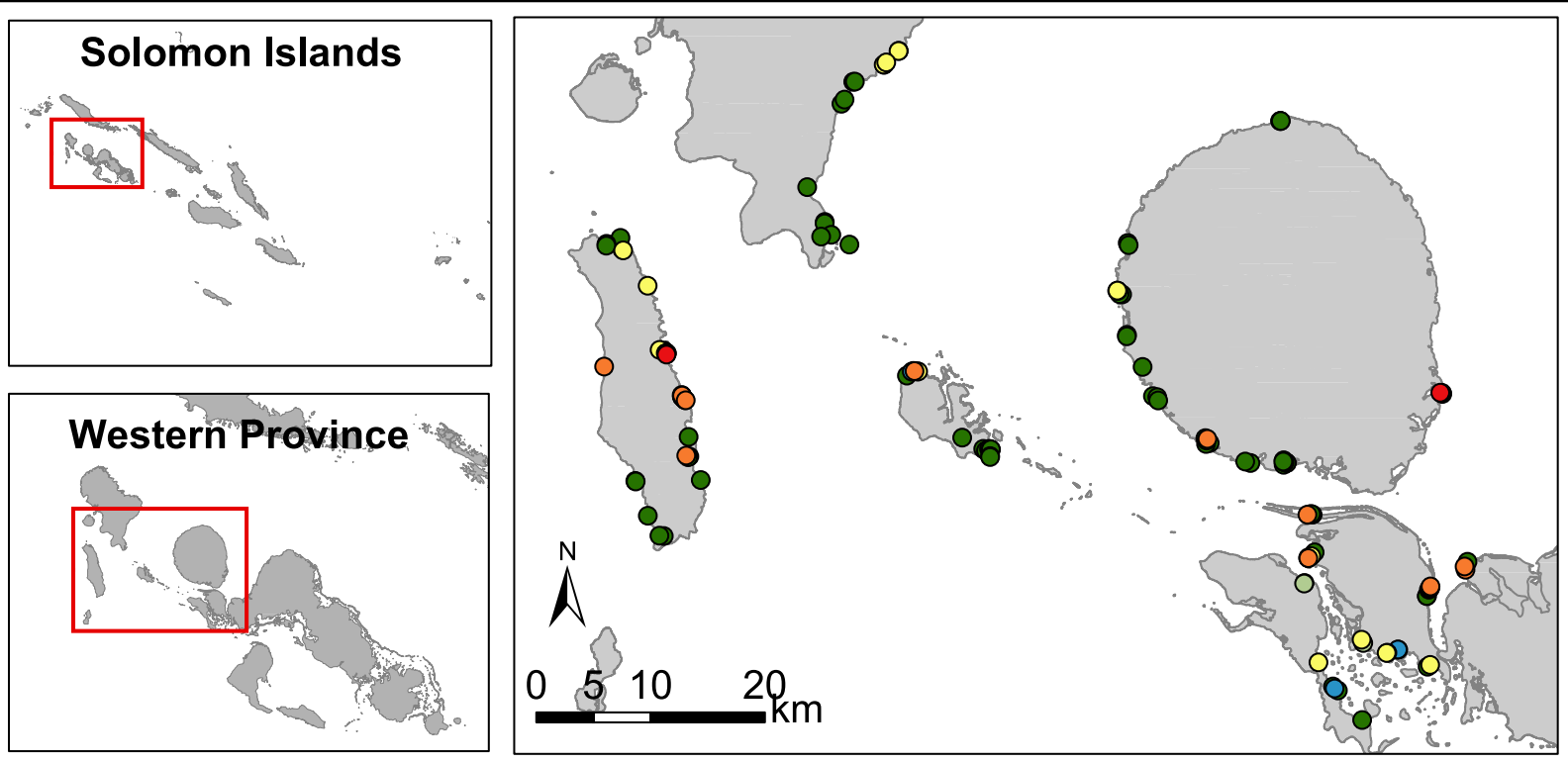

\section{Legend}

Species

- farauti

- farauti, nataliae

nataliae

- farauti, hinesorumo lungae

- farauti, lungae

○ lungae, hinesorum

Fig. 4 Species distribution of Anopheline fauna based on larval surveys conducted in Western Province, Solomon Islands. The Islands included in the survey were Vella Lavella, Ranonnga, Gizo, Kolombangara, Vonavona, Kohinggo and New Georgia Islands

Table 1 Aquatic larval habitats utilized by the five anopheline species found in Central and Western Provinces, Solomon Islands

\begin{tabular}{llllll}
\hline $\begin{array}{l}\text { Habitat } \\
\text { type }\end{array}$ & \multicolumn{4}{l}{ Species and number of sites occupied (\%) } & \\
\cline { 2 - 6 } & $\begin{array}{l}\text { An. } \\
\text { farauti }\end{array}$ & $\begin{array}{l}\text { An. hine- } \\
\text { sorum }\end{array}$ & $\begin{array}{l}\text { An. } \\
\text { lungae }\end{array}$ & $\begin{array}{l}\text { An. } \\
\text { nataliae }\end{array}$ & $\begin{array}{l}\text { An. solo- } \\
\text { monis }\end{array}$ \\
\hline $\begin{array}{l}\text { Lagoon or } \\
\text { swamp }\end{array}$ & $19(55.9)$ & $20(45.5)$ & $4(26.7)$ & $4(40.0)$ & $0(0.0)$ \\
$\begin{array}{l}\text { Drains } \\
\begin{array}{c}\text { Transient } \\
\text { pools }\end{array}\end{array}$ & $3(8.8)$ & $8(18.2)$ & $1(6.7)$ & $0(0.0)$ & $0(0.0)$ \\
$\begin{array}{l}\text { Man- } \\
\text { made } \\
\text { holes }\end{array}$ & $7(20.6)$ & $5(11.4)$ & $0(0.0)$ & $1(10.0)$ & $1(50.0)$ \\
$\begin{array}{l}\text { Riverine } \\
\begin{array}{l}\text { Spring } \\
\text { well }\end{array}\end{array}$ & $1(2.9)$ & $7(15.9)$ & $7(46.7)$ & $4(40.0)$ & $1(50.0)$ \\
\hline
\end{tabular}

After the 2009 faunal surveys in Santa Isabel, it was proposed that increased competition for larval sites by $A n$. hinesorum may have inhibited the prevalence and range of An. punctulatus and An. koliensis [5]. This is significant for malaria transmission because $A n$. hinesorum in the Solomon Islands is primarily zoophagic (e.g., a non-vector of human malaria) [5, 10, 37]. On Santa Isabel, Central and Western Provinces, An. hinesorium occupied sites normally associated with An. punctulatus and An. koliensis such as drains and semi-permanent ground pools. The larval surveys in this study only focused on coastal areas because this is where most villages (and malaria) are found and this would have excluded freshwater sites distant from the coast.

The distribution of $A n$. farauti larvae was not uniform among five sampling sites within a large coastal lagoon. The density and presence of larvae was highest at the proximal and distal sites relative to the sandbar that created the lagoon but this was not associated with either temperature or salinity. Similar studies on Guadalcanal during 2007-08 [19] also found that An. farauti distribution was not uniform within large coastal larval habitats. While the habitats in Guadalcanal and Central Provinces were both coastal and were formed when water flow into 
Table 2 Spatial comparison of An. farauti larval occurrence and environmental factors recorded in the study lagoon in Haleta Village, Central Province, Solomon Islands

\begin{tabular}{|c|c|c|c|c|}
\hline \multirow[b]{2}{*}{ Location } & \multicolumn{2}{|c|}{ Larval occurrence } & \multicolumn{2}{|c|}{ Environmental factors } \\
\hline & $\begin{array}{l}\text { Density } \\
\text { per dip }^{a}\end{array}$ & $\begin{array}{l}\text { Presence } \\
\text { (daily) }^{\mathbf{b}}\end{array}$ & Temp $\left({ }^{\circ} \mathrm{C}\right)$ & Salinity (ppt) \\
\hline 1 & $1.79 \pm 0.39$ & $1.0 \pm 0.0$ & $31.6 \pm 0.3$ & $1.0 \pm 0.7$ \\
\hline 2 & $0.73 \pm 0.15$ & $0.8 \pm 0.1$ & $31.0 \pm 0.3$ & $0.6 \pm 0.6$ \\
\hline 3 & $0.26 \pm 0.06$ & $0.8 \pm 0.1$ & $30.9 \pm 0.2$ & $0.4 \pm 0.4$ \\
\hline 4 & $0.20 \pm 0.07$ & $0.5 \pm 0.2$ & $31.1 \pm 0.3$ & $0.0 \pm 0.0$ \\
\hline 5 & $1.10 \pm 0.24$ & $1.0 \pm 0.0$ & $30.8 \pm 0.3$ & $0.0 \pm 0.0$ \\
\hline
\end{tabular}

Data presented are mean \pm se

a Mean larval density per dip over 10 days

b Presence of mosquito larvae was defined as the proportion of 10 dips in which larvae of any stage were present

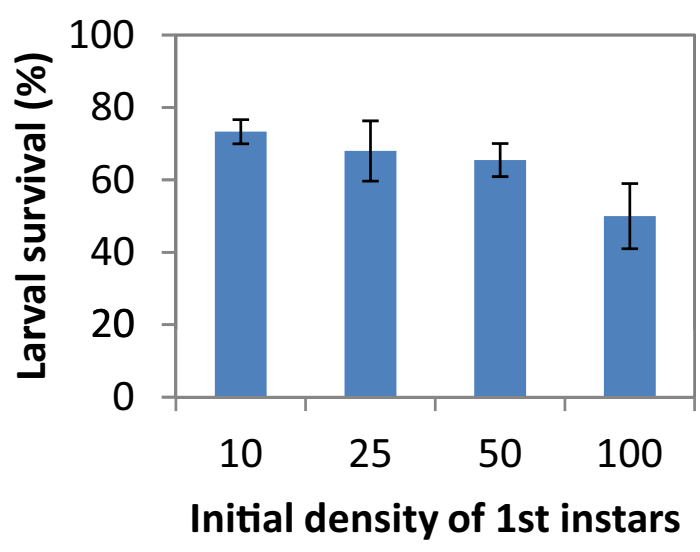

Fig. 5 The survival of An. farauti larvae after being held in mesh cages for 9 days at different densities. Note: larval survival was defined as total larval present divided by the total released into the cage

the ocean was blocked by a sand mouth, the Guadalcanal sites were larger streams that were blocked by sandbars whereas the site in Central Province was a lagoon resulting from surface water runoff trapped by a sandbar from flowing into the ocean. On Guadalcanal the density and prevalence of larvae was highest near the mouth of the steam and declined as the sampling stations moved inland where the water became deeper and faster flowing. On Guadalcanal, larval densities were also positively associated with aquatic emergent plants and filamentous algae [19].

Evidence for potential density dependent development effects were seen within the river-mouth lagoon. The survival of larvae at the highest density in the cages was nearly two-fold less than that when held at the lowest density. Confirming density dependent impacts will require careful quantitative documentation of the density of larvae in natural habitats and the impacts of density on adult mosquito fitness; in addition potential density dependent impacts will need to be teased apart from exogenous influences. The implications of density dependent effects for malaria control remain unclear. Potentially, if anopheline growth is under strong density dependent regulation, control measures may become proportionately less effective as larval densities diminish because the remaining individuals could compensate with enhanced reproduction and survival [38, 39]. Understanding the concurrent roles of exogenous and density dependent factors on population growth is crucial for predicting the response of vector populations to control strategies.

\section{Conclusion}

Anopheline surveys in two provinces found an extensive distribution of $A n$. farauti but did not find either $A n$. punctulatus or An. koliensis. This suggests that these two formerly dominant malaria vectors, An. punctulatus and An. koliensis, are uncommon if not eliminated from Central and Western Provinces. The primary vector, An. farauti, remains and has a habit of feeding early and outdoors when humans are not protected by LLINs and IRS. While the primary larval habitat of $A n$. farauti in the Solomon Islands are river-mouth lagoons and large swamps which are "few (in number), fixed (permanent) and findable (located close to villages)" [40] and thereby fulfil, in theory, the attributes that should make these larval habitats amenable to LSM, it is unclear if the large size of these habitats are "fixable" without more information on the distributions and densities of larvae within the complex habitats (swamps encompassing extensive vegetation an multiple microhabitats) that they occupy.

\section{Availability of data and materials}

The datasets supporting the conclusions of this article are available in the James Cook University Tropical Data Hub repository: $10.4225 / 28 / 56 \mathrm{C} 65$.

\section{Abbreviations}

GLM: generalized linear model; GLMM: generalized linear mixed model; HLC: human landing catch; HR: hazard ratio; IRS: indoor residual spraying; LLINs: long-lasting insecticidal nets; LSM: larval source management.

\section{Authors' contributions}

TLR supervised the field studies and drafted the manuscript. NFL supervised the host density studies. TLR, NFL, FHC and TRB contributed to the experimental designs. All authors participated in the field experiments. RDC and WKC conducted the molecular analyses. All authors read and approved the final manuscript. 


\section{Author details}

1 Australian Institute of Tropical Health and Medicine, James Cook University, Cairns, QLD 4870, Australia. ${ }^{2}$ National Vector Borne Disease Control Programme, Ministry of Health, Honiara, Solomon Islands. ${ }^{3}$ School of Biological Sciences, University of Queensland, St. Lucia, QLD 4068, Australia. ${ }^{4}$ CSIRO, Dutton Park, Brisbane, QLD 4102, Australia. ${ }^{5}$ Australian Army Malaria Institute, Gallipoli Barracks, Enoggera 4052, Australia. ${ }^{6}$ Eck Institute for Global Health, Department of Biological Sciences, University of Notre Dame, Notre Dame, IN 46556, USA.

\section{Acknowledgements}

This work was supported by Grant No. 45114 from the Bill and Melinda Gates Foundation to the Malaria Transmission Consortium for the work in the Solomon Islands. In addition, the support of the National Institute of Allergy and Infectious Diseases of the National Institutes of Health for the International Center of Excellence in Malaria Research in the Southwest Pacific (subaward to James Cook University; award number U19A108986) is gratefully acknowledged. The content is solely the responsibility of the authors and does not necessarily represent the official views of the funders or the Australian Defence Force and/or extant Defence Force Policy.

Technical assistance was provided by staff of the Vector Borne Disease Control Programme, Solomon Islands, in particular in Central Province John Lodo and in Western Province Hedrick Reuben and Jance Oscar. The PCR analysis of larval specimens was conducted at The Australian Army Malaria Institute. The authors thank the communities for their support as well as the support of Mr Albino Bobogare, Director of National Vector Borne Disease Control Programme, Solomon Islands and Prof James Kazura, Programme Director of the International Center of Excellence in Malaria Research in the Southwest Pacific.

\section{Competing interests}

The authors declare that they have no competing interests.

Received: 14 November 2015 Accepted: 26 February 2016

Published online: 15 March 2016

\section{References}

1. Russell TL, Beebe NW, Bugoro H, Apairamo A, Cooper RD, Lobo NF et al. Anopheles farauti is a homogeneous population that blood feeds early and outdoors in the Solomon Islands. Malar J. 2016. doi:10.1186/ s12936-016-1194-9.

2. Taylor B. Changes in the feeding behaviour of a malaria vector, Anopheles farauti Lav, following the use of DDT as a residual spray in houses in the British Solomon Islands Protectorate. Trans R Entomol Soc London. 1975;127:227-92.

3. Paik Y-H, Avery JG. Problem areas in the malaria eradication programme in the British Solomon Islands. PNG Med J. 1973;17:61-7.

4. Bugoro H, Cooper R, Butafa C, Iro'ofa C, Mackenzie D, Chen C-C, et al. Bionomics of the malaria vector Anopheles farauti in Temotu Province, Solomon Islands: issues for malaria elimination. Malar J. 2011;10:133. doi:10.1186/1475-2875-10-133.

5. Bugoro H, Iro'ofa C, Mackenzie D, Apairamo A, Hevalao W, Corcoran S, et al. Changes in vector species composition and current vector biology and behaviour will favour malaria elimination in Santa Isabel Province, Solomon Islands. Malar J. 2011;10:287. doi:10.1186/1475-2875-10-287.

6. Bugoro H, Hii J, Butafa C, Iroofa C, Apairamo A, Cooper R, et al. The bionomics of the malaria vector Anopheles farauti in Northern Guadalcanal, Solomon Islands: issues for successful vector control. Malar J. 2014;13:56. doi:10.1186/1475-2875-13-56.

7. Russell TL, Beebe NW, Bugoro H, Apairamo A, Chow W, Cooper RD et al. Frequent blood feeding enables insecticide-treated nets to reduce transmission by mosquitoes that bite predominately outdoors. Malar J. 2016. doi:10.1186/s12936-016-1195-8.

8. WHO. Larval source management-a supplementary measure for malaria vector control. An operational manual. Geneva: World Health Organization; 2013.

9. Tusting Lucy S, Thwing J, Sinclair D, Fillinger U, Gimnig J, Bonner

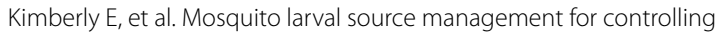

malaria. Cochrane Database Syst Rev. 2013;8:923. doi:10.1002/14651858. CD008923.pub2.

10. Beebe NW, Bakotee H, Ellis JT, Cooper RD. Differential ecology of Anopheles puntucaltus and three members of the Anopheles farauti complex of mosquitoes on Guadalcanal, Solomon Islands, identified by PCR-RFLP analysis. Med Vet Entomol. 2000;41:308-12.

11. Schmidt ER, Foley DH, Bugoro H, Bryan JH. A morphological study of the Anopheles punctulatus group (Diptera: Culicidae) in the Solomon Islands, with a description of Anopheles (Cellia) irenicus Schmidt, sp. n. Bull Entomol Res. 2003;93:515-26. doi:10.1079/BER2003267.

12. Belkin JN. The mosquitoes of the South Pacific (Diptera, Culicidae). Berkeley and Los Angeles: University of California Press; 1962.

13. Taylor B. Observations on malaria vectors of the Anopheles punctulatus complex in the British Solomon Islands Protectorate. J Med Entomol. 1975; 11:677-87.

14. Sweeney AW. Larval salinity tolerances of the sibling species of Anopheles farauti. J Am Mosq Control Assoc. 1987;8(4):589-92.

15. Bell D, Bryan J, Cameron A, Foley D, Pholsyna K. Salinity tolerance of Anopheles farauti Laveran sensu stricto. PNG Med J. 1999;42:5-9.

16. Cooper RD, Waterson DGE, Frances SP, Beebe NW, Sweeney AW. Speciation and distribution of the members of the Anopheles punctulatus (Diptera: Culicidae) group in Papua New Guinea. J Med Entomol. 2002;39:16-27.

17. Daggy RH. The biology and seasonal cycle of Anopheles farauti on Espirtu Santo, New Hebrides. Ann Entomol Soc Am. 1945;38:3-13.

18. Sweeney AW. Variations in density of Anopheles farauti Laveran in the Carteret Islands. PNG Med J. 1968;11:11-8.

19. Bugoro H, Hii J, Russell T, Cooper R, Chan B, Iro'ofa C, et al. Influence of environmental factors on the abundance of Anopheles farauti larvae in large brackish water streams in Northern Guadalcanal, Solomon Islands. Malar J. 2011;10:262. doi:10.1186/1475-2875-10-262.

20. Hii JLK, Kanai L, Foligela A, Kan SKP, Burkot TR, Wirtz RA. Impact of permethrin-impregnated mosquito nets compared with DDT house spraying against malaria transmission by Anopheles farauti and An. punctulatus in the Solomon Islands. Med Vet Entomol. 1993;7:333-8.

21. Hii JLK, Birley MH, Kanai L, Foligeli A, Wagner J. Comparative effects of permethrin-impregnated bednets and DDT house spraying on survival rates and oviposition interval of Anopheles farauti No. 1 (Diptera: Culicidae) in Solomon Islands. Ann Trop Med Parasitol. 1995;89:521-9.

22. Brook BW, Bradshaw CJA. Strenght of evidence for density dependence in abundance time series of 1198 species. Ecology. 2006;87:1445-51. doi:10.1890/0012-9658(2006)87\%5B1445:SOEFDD\%5D2.0.CO;2.

23. Sibly RM, Barker D, Denham MC, Hone J, Page M. On the regulation of populations of mammals, birds, fish and insects. Science. 2005;309:60710. doi:10.1126/science.1110760.

24. Yang G-J, Brook BW, Whelan PI, Cleland S, Bradshaw CJA. Endogenous and exogenous factors controlling temporal abundance patterns of tropical mosquitoes. Ecol Appl. 2008;18:2028-40. doi:10.1890/07-1209.1.

25. Russell TL, Lwetoijera DW, Knols BGJ, Takken W, Killeen GF, Ferguson HM. Linking individual phenotype to density-dependent population growth: the influence of body size on the population dynamics of malaria vectors. Proc R Soc Lond B. 2011;278:3142-51. doi:10.1098/ rspb.2011.0153.

26. Gimnig JE, Ombok M, Otieno S, Kaufman MG, Vulule JM, Walker ED. Density-dependent development of Anopheles gambiae (Diptera: Culicidae) larvae in artificial habitats. J Med Entomol. 2002;39:162-72.

27. Ng'habi KR, John B, Nkwenguilia G, Knols BGJ, Killeen GF, Ferguson HM. Effect of larval crowding on mating competitiveness of Anopheles gambiae mosquitoes. Malar J. 2005;4:49. doi:10.1186/1475-2875-4-49.

28. Lyimo E, Takken W, Koella JC. Effect of rearing temperature and larval density on larval survival, age at pupation and adult body size of Anopheles gambiae. Entomol Exp Appl. 1992;63:265-71.

29. Brookfield HC, Hart D. Rainfall in the tropical southwest Pacific. Canberra: Department of Geography, Publ G/3, The Australian National University; 1966.

30. Beebe NW, Saul A. Discrimination of all members of the Anopheles punctulatus complex by polymerase chain reaction - restriction fragment length polymorphism analysis. Am J Trop Med Hyg. 1995;53:478-81.

31. Russell TL, Beebe NW, Bugoro H, Apairamo A, Cooper RD, Lobo NF et al. Determinants of host feeding success by Anopheles farauti. Malar J. 2016. doi:10.1186/s12936-016-1168-y. 
32. Russell TL, Burkot TR, Bugoro H, Apairamo A, Beebe NW, Chow WK et al. Data archive: Larval habitats of the Anopheles farauti and Anopheles lungae complexes in the Solomon Islands. James Cook University Tropical Data Hub; 2016. [Data Files]. doi:10.4225/28/56C6511C9B57D.

33. Core Team R. R: A language and environment for statistical computing. Vienna: R Foundation for Statistical, Computing; 2013

34. Spencer T, Spencer M, Venters D. Malaria vectors in Papua New Guinea. PNG Med J. 1974;17:22.

35. Slooff R. Observations on the effect of residual DDT house spraying on behaviour and mortality in species of the Anopheles punctulatus group. Final report on a research project in West New Guinea [PhD Thesis]. Leyden: University of Leyden; 1964.

36. Samarawickrema WA, Parkinson AD, Kere N. Seasonal abundance and biting behaviour of Anopheles punctulatus and An. koliensis in Malaita Province, Solomon Islands, and a trial of permethrin impregnated bednets against malaria transmission. Med Vet Entomol. 1992;6:371-8.
37. Foley DH, Meek SR, Bryan JH. The Anopheles punctulatus group of mosquitoes in the Solomon Islands and Vanuatu surveyed by allozyme electrophoresis. Med Vet Entomol. 1994;8:340-50.

38. Kokko H. Optimal and suboptimal use of compensatory responses to harvesting: timing of hunting as an example. Wildl Biol. 2001;7:141-50.

39. Cameron TC, Benton TG. Stage-structured harvesting and its effects: an empirical investigation using soil mites. J Anim Ecol. 2004;73:996-1006. doi:10.1111/j.0021-8790.2004.00886.x.

40. WHO. Interim position statement - the role of larviciding for malaria control in sub-Saharan Africa. Geneva: World Health Organization; 2012.
Submit your next manuscript to BioMed Central and we will help you at every step:

- We accept pre-submission inquiries

- Our selector tool helps you to find the most relevant journal

- We provide round the clock customer support

- Convenient online submission

- Thorough peer review

- Inclusion in PubMed and all major indexing services

- Maximum visibility for your research

Submit your manuscript at www.biomedcentral.com/submit
Biomed Central 